Vol. 5, n`2 | 2001

Varia

\title{
Rectifying Public Morals in Interwar Japan
}

Elise K. Tipton

\section{(2) OpenEdition}

\section{Journals}

Electronic version

URL: https://journals.openedition.org/chs/1063

DOI: $10.4000 /$ chs. 1063

ISSN: 1663-4837

\section{Publisher}

Librairie Droz

\section{Printed version}

Date of publication: 1 January 2001

Number of pages: 133-148

ISBN: 2-600-00664-8

ISSN: 1422-0857

\section{Electronic reference}

Elise K. Tipton, "Rectifying Public Morals in Interwar Japan", Crime, Histoire \& Sociétés / Crime, History \& Societies [Online], Vol. 5, n² | 2001, Online since 06 April 2009, connection on 23 March 2022. URL: http://journals.openedition.org/chs/1063 ; DOI: https://doi.org/10.4000/chs.1063

(c) Droz 


\title{
Rectifying Public Morals in Interwar Japan
}

\author{
Elise K. Tipton ${ }^{1}$
}

This study of growing restrictions on cafés in Japan during the 1920s and 1930 s provides a case study of moral regulation as a form of politics defined in a broad sense. Governmental authorities cracked down on cafés which they perceived to be the source of threats to established social norms and gender roles posed by «modern», Western trends of the 1920s. The repression demonstrates that Japan's prewar crisis was as much domestic and social as it was international and political. The Japanese police had played a social role in moral regulation since the Meiji period (1868-1912), but this was further expanded in the conflict over modernity.

Cette étude porte sur les restrictions croissantes imposées aux cafés dans le Japon des années 1920 et 1930. Elle présente un cas de police des mours comme un aspect de la politique, au sens large du terme. Les autorités gouvernementales réprimèrent les cafés parce qu'elles voyaient l'origine des menaces que la vogue «moderne» inspirée de l'Occident faisait peser sur les normes sociales et les rôles sexuels établis. La répression montre que la crise japonaise d'avant-guerre était tout autant interne et sociale qu'internationale et politique. La police japonaise intervenait dans la régulation des maurs depuis l'ère Meiji (1868-1912), mais le conflit relatif à la modernité donna une nouvelle expansion à ce rôle.

The duties [of the administrative police] consist of four matters-rights, health,
public morals and national affairs

1. To protect the people's rights and make them pursue their business in peace;

2. To protect life by nursing health;

3. To rectify public morals by suppressing dissipation and debauchery;

1 Elise Tipton is a Senior Lecturer in Japanese Studies at the University of Sydney. She is the author of The Japanese Police State: The Tokkô in Interwar Japan, editor of Society and the State in Interwar Japan, and co-editor of Being Modern in Japan. This paper is part of ongoing research on the relationship between society and the state, based on case studies of the birth control movement and attitudes and policies toward poverty as well as the café in modern Japanese urban life. Initial research for this project was made possible by the Extended Research Secondment scheme of the Research Institute for Humanities and Social Sciences, University of Sydney, during the second semester of 1998. Thanks also to my research assistant, Ms Ikuko Sorensen. I hope that revisions following from suggestions made by the two anonymous readers for this journal help to make this study more interesting and comprehensible to those unfamiliar with Japanese history. 
4. To investigate in secrecy and guard against political crimes.

Keishichô Organizational Regulations and Other Rules, $1874^{2}$

In 1926 the Tokyo Metropolitan Police (Keishichô) made 645 arrests in cafés and bars throughout the city ${ }^{3}$. In 1938 over 2,000 arrests were made in one night in cafés, bars and dance halls in entertainment districts in the city, based on a series of more severe restrictions imposed on cafés and dance halls during the intervening years ${ }^{4}$. The contemporary Marxian psychologist Tosaka Jun ${ }^{5}$ saw through the underlying intent of these restrictions on public morals. Although government authorities presented the restrictions as part of an educational plan to raise the people's morals, he argued that in fact the interference had an ideological intent of thought control. In the interwar Japanese context «thought» (shisô) usually referred to political ideas and ideologies, and «dangerous thought» meant radical socialism and communism. In Tosaka's words, thought was something that appeared as public morals and public morals symbolized thought. Consequently, any attempt to control public morals was actually an attempt to control thought ${ }^{6}$. Although I would use somewhat different vocabulary, a closer look at the history of restrictions on cafés during the 1920 s and 1930s suggests that Tosaka was perceptive in seeing the political implications of Japanese authorities' efforts to control public morals.

However, we need to define «political» implications in a broad sense. As Alan Hunt has pointed out, «moral regulation projects are an interesting and significant form of politics in which some people act to problematise the conduct, values or culture of others and seek to impose regulation upon them ${ }^{7}$. Moreover, "while moral politics is often complexly linked to the pursuit of economic or other interests, such politics is never reducible to a smokescreen or cover for more mundane class or sectional interests $»^{8}$. The tighter restrictions and control of cafés, bars and dance halls in the late 1920 s and 1930 s were only partially related to Japanese police authorities' concern that leftist political thought would spread through conversations taking place in cafés. In the 1920s and 1930s government officials were concerned with the social ideas and behaviour associated with the café as site and symbol of modernity and «modern life» (modan seikatsu) as well as with the socialist political ideas that might be circulated within it. And it was not only government officials who were disturbed by the social changes reflected in the café, but also a wide spectrum of social commentators ranging from conservative traditionalists through middle class Christian moral reformers to left wing Marxian intellectuals. As in moral regulation movements in Britain and the United States during the nineteenth and twentieth centuries ${ }^{9}$, a wide range of social agencies were involved in a contested process of expanding controls over public morals in Japan during the the interwar years. Middle class groups were particularly active in pressing for

\footnotetext{
Quoted in Kuroda (1963, p. 239).

Keishichôshi Hensan linkai (1962, p. 810).

Keishichôshi Hensan linkai (1962, p. 829).

Please note that Japanese names are given in Japanese order, which is surname first.

Tosaka (1983, p. 47).

Hunt (1999, p. 1).

Hunt (1999, p. ix).

9 See Hunt (1999) for a comparative study of such movements.
} 
stricter regulation of cafés and of café waitresses involved in unlicensed prostitution $^{10}$.

Here, however, the focus will be on state regulation of public morals, and especially the role of the police as an agent of moral regulation. Police control of cafés and dance halls exemplifies the wide-ranging responsibilities of the modern Japanese police from its inception in the Meiji period ${ }^{11}$ (1868-1912) to the end of the Second World War, as revealed in the regulations of the Tokyo Metropolitan Police quoted above. From the beginning, police duties and responsibilities encompassed control of public morals, which included licensed and unlicensed prostitution. Police control of the café, its employees and its patrons therefore reveals certain continuities in the social role of the modern Japanese police, but it was an expanded role representing the state's response to social developments specific to $1920 \mathrm{~s}$ and 1930s Japan. The conservative Japanese police institution increasingly intervened in social life in an attempt to check what were perceived as threats to officially sanctioned social values and roles posed by the «modern» trends of the $1920 \mathrm{~s}$.

\section{THE POLICE TRADITION FROM THE MEIJI PERIOD}

Because the organization and functions of the police system remained fundamentally unchanged from the late Meiji period, the consciousness of historical traditions was strong among interwar police officials. Police intervention in Japanese social life derived from the «nursemaid» ideal envisioned for the police by its founder, Kawaji Toshiyoshi. Kawaji's descriptions of the police as the remedy for national peace and nurturer of the people implied tasks of moral guidance and education as well as peace preservation and crime detection.

In their attempt to catch up to the major Western imperialist powers, the Meiji leaders after coming to power in 1868 looked for Western models on which to base new governmental structures and institutions. In the case of the police, the government also sought Western models, but concern for putting down political resistance and securing domestic peace shaped the model chosen. Consequently, when Kawaji left in 1872 to investigate various European police systems, Britain was omitted from his itinerary in favour of Continental countries whose police systems embodied national, centralized control and both political and social functions ${ }^{12}$. Upon his return, Kawaji recommended a system based on the French rather than the British or American model of police.

As in the French system, the police would belong to an interior ministry with jurisdiction over the police of the entire country rather than being responsible to local and autonomous administrative units, as in Britain and the United States. Home Ministry officials of the 1930s proudly pointed out that the Japanese police system was even more unified and centralized than its French, and later German, models since the Home Minister possessed authority over all police policy matters

10 The Protestant Purity Association (Kakuseikai) was prominent among these.

11 Meiji refers to the reign name of the emperor. The Meiji emperor reigned from 1868-1912, the Taishô emperor from 1912-1926, the Shôwa emperor from 1926-1989, and the present Heisei emperor since 1989.

12 Westney (1987, p. 41). 
in the country. Below him the key police officials were the Superintendent-General of the semi-independent Keishichô in Tokyo and the Director of the Police Bureau, who exercised administrative and operational control over all prefectural departments except the Keishichô. The latter's chief means of control lay in his authority to appoint and transfer police officials in the rank of superintendent or above from among the higher civil service administrators in the ministry. These included the chiefs of prefectural police divisions who, in practice, were left with responsibility for routine management and most law enforcement duties.

In line with Continental European usage tracing back to the Polizeistaat, the Meiji founders employed the term "police» in the broad seventeenth and eighteenth-century sense of all internal administration rather than the narrow sense of crime prevention and detection, as adopted by the British and Americans ${ }^{13}$. Consequently, the range of police activities was wide, as indicted by the names of the major branches of the police: sanitation and health, traffic, firefighting, public morals, peace preservation. In addition, police powers were great, again adopting continental views of wide preventive as well as prohibitive powers. Like the German police, which became the model for police reforms during the $1880 \mathrm{~s}$, the Japanese police could issue ordinances having the force of laws and perform judicial functions in certain cases, punishing particular types of legal violations, such as minor offences ${ }^{14}$. Police legislation was not confined to prohibiting certain actions viewed as detrimental to public welfare, as in Britain, but also prescribed behaviour which would make repression unnecessary. The extensive use of administrative ordinances for supervisory purposes, which we will see in the case of regulating cafés, followed the continental conception of laws as rules of conduct. It was in keeping with the adoption of German constitutionalism and the principle of rule by law (Rechsstaatprinzip), as distinct from rule of law. This entailed formal commitment to administration under the law, but gave the executive wide legislative power and left police and other administrative officials substantively outside the control of justiciable law ${ }^{15}$.

Emphasis on this supervisory and preventive role of the police appeared in Kawaji's «Hand and Eye of the Police», which one writer in the 1920s described as the sacred book of the police like the Bible or Koran ${ }^{16}$. In it Kawaji highlighted the nurturing role of the police, portraying it as the «nursemaid» to the people. He likened the country to a family with the government as parents, the people as children and the police as their nursemaid. While stressing the need for police officers to be kind and patient, he also stressed that the Japanese people were still unenlightened and therefore particularly childish. The people needed to rely on the care of the nursemaid-police, and since the government had a duty to teach the people, like a parent's duty to a child, it must teach the people even if they disliked it. According to the nursemaid ideal, police officials stood in a hierarchical relationship between the emperor-parent and the people-children. Their attitude towards the people was paternalistic. This involved concern for their education, welfare and moral wellbeing, but at the same time implied feelings of superiority and authority. This further

13 Fosdick (1916, p. 23).

14 Fosdick (1916, pp. 18-20, 23-25).

is For a more in-depth discussion, see Tipton (1991, ch. 3).

16 Kamiyanagi (1925, pp. 18-19). 
implied an expectation of submission and compliance by the people, and that obedience might be obtained by force, just as a nanny might discipline her charges «for their own good».

Given the nursemaid ideal, supervising public morals certainly came within the realm of responsibilities envisioned for the modern police system established during the Meiji period. To win acceptance as an «enlightened» and «civilized» equal to Western societies, the Meiji government introduced reforms to change social behaviour and customs, such as criminalization of abortion. There were also prohibitions against public nakedness and mixed sex public baths which Westerners found offensive and attempts to ban pornographic «spring pictures» (shunga) and lewd plays.

As in the previous Tokugawa period, however, prostitution remained legal, though segregated. Licensed brothel areas continued to be designated in cities so that they could be supervised, and police authorities harassed and arrested unlicensed prostitutes. According to the official history of the Tokyo Metropolitan Police Bureau, control of prostitution itself was not intended; rather, the main aim was control of the patrons ${ }^{17}$. Again, this continued Tokugawa policies which had originally established official brothel quarters in cities for «security» reasons, namely to control unemployed samurai and other unruly elements ${ }^{18}$. Responsibility for regulating prostitution was delegated to the prefectures, but prefectural authorities worked closely with central Home Ministry officials. Following the lead of the Tokyo Metropolitan Police, they adopted many of the regulatory practices of the Paris police (such as periodic medical inspections of licensed prostitutes), but went further in restricting the liberties of the prostitute in order to achieve more effective regulation. Notably, unlike Western European regulations, the Home Ministry's Rules Regulating Licensed Prostitutes (1900) effectively bound prostitutes to their licensed houses and owners by prohibiting their working or living outside the brothels, so that independent registered prostitutes did not emerge in Japan as they did in late nineteenth century France and Italy ${ }^{19}$. The desire for effective regulation was evident from the beginning. In the early 1870 s both the national and Tokyo governments issued laws prohibiting unlicensed prostitution (shish $\hat{o}$, literally private prostitution), but soon repealed them for fear that revealing the existence of illegal prostitution would lead Westerners to deride Japan as barbarous. New penal regulations for «prostitution» were issued to control both unlicensed and licensed prostitution, but by using a different word, did not reveal the existence of prostitution which might escape government control $^{20}$.

The tradition inherited by the police of the 1920s thus consisted of three main elements: a centralized organization and structure under Home Ministry control, pervasive powers and functions, and an ideology of service to the state and paternalism towards the people. While by no means a fixed or static legacy, like other governmental institutions, the police structure did not change fundamentally after the Meiji period. Moreover, Japanese political leaders, including bureaucrats and

17 Keishichôshi Hensan linkai (1959, p. 103).

18 Teruoka (1989, pp. 4-5).

19 Although the Rules recognized a prostitute's right of free cessation, in practice it was difficult because they could rarely pay off the advance money paid to them or their parents and other debts incurred; Garon (1997, pp. 92-93).

20 Keishichôshi Hensan linkai (1959, pp. 183-184). 
political party leaders emerging to positions of power in the cabinet, were not interested in introducing policies designed to transform Japan radically as in the early Meiji period.

In the years following the First World War the social and political elites both outside and inside government who dominated policy-making faced new challenges to their values and norms for social behaviour. The interwar years witnessed tremendous social and political change, but no longer under the guidance and promotion of the state. They constitute a period when elements of a modern society became clearly visible: the shift from a rural, agricultural to an urban, industrialized society, the beginnings of a consumer society, and the proliferation of mass media. There were also newly organized demands for social justice, freedom, equality and political representation put forward by women and minorities as well as industrial workers and tenant farmers. These emerged out of dissatisfaction with the dislocations and unequally distributed burden of industrialization, but were also influenced by a new wave of Western social and political ideas. Many of these trends can be discerned in the development of the café and its culture, and police authorities' responses to them reflect the clash over modernity which culminated in the repressive authoritarianism and aggressive expansionism of the late 1930s and 1940s.

\section{THE CAFÉ IN MODERN JAPANESE URBAN LIFE}

From a Westerner's point of view, one might wonder why the police were so concerned about cafés, but Japanese cafés of the 1920s and 1930s were unlike any cafés that Westerners would most likely envisage.

The first cafés which appeared in Japan at the end of the Meiji period resembled their European, especially French, models more closely. They served Western food and coffee, and they attracted a clientele of mostly writers, artists and intellectuals. In fact, the first one in Tokyo, named «Café Printemps» (Kafê Purantan), was owned by the Western-style painter Matsuyama Shôzô. Café Printemps and other early cafés thus served as European-style salons where intellectuals could talk freely, eat Western food and enjoy Western cocktails, sitting around on wooden chairs at tables with white tablecloths while being served by elegant waitresses dressed demurely in traditional kimonos and white aprons. Cafés up until the great Kantô earthquake of 1923 were places where one ate Western food, which was still rather a novelty, and where service was of secondary importance.

According to many contemporary commentators, this changed after the earthquake, raising new challenges to police supervision of public morals. It is no exaggeration to describe the decade after the earthquake as «the café era». The number of cafés and café waitresses rose so sharply and rapidly that contemporaries referred to «massification" (taish ûka). In 1922 there were 20 cafés on the main street of the Ginza district, the centre of fashionable shops, department stores and restaurants; in 1929 there were $50^{21}$. In 1925 a Central Employment Agency survey counted 7319 café waitresses in Tokyo and 4230 in Osaka ${ }^{22}$. According to a police survey just four years later, the number of waitresses in Tokyo had jumped to 15559 , working in

21 Murashima (1988, p. 373).

22 Dôke (1988, p. 279). 
6187 cafés and 1345 bars $^{23}$. A later national survey in 1940 found that there had been 27532 cafés and bars throughout the country and 66840 waitresses in 1930 . The number of cafés and bars climbed to a peak of 37065 in 1934 and thereafter declined to 29064 in 1940 . The number of waitresses, however, continued to increase beyond 1934, reaching a height of 111700 in 1936 . Although their numbers declined thereafter, there were still 91946 waitresses in the country in $1940^{24}$.

In Tokyo after the earthquake cafés had sprouted up «like bamboo shoots after a rain» all over the city ${ }^{25}$, but were concentrated in entertainment districts known as «sakariba»' (literally, bustling places) such as Ginza, Asakusa, Kanda, Shinjuku and Shibuya. Of these, Ginza represented the most modern and up-to-date as well as the classiest and the most elegant. After the earthquake many large cafés appeared on the main street of Ginza and also dozens of small cafés in the back streets, but it was not just greater numbers and the larger scale of the establishments that created «the cafe era» and new characteristics of the modern. As in pre-earthquake times, modern still meant Western, which is reflected in the names of the new cafés and bars being derived from English - Gondora (Gondola), Ginza Paresu (Ginza Palace) and Gurando Ginza (Grand Ginza). Their architecture and interior decor also continued to be foreign inspired, but increasingly by the United States rather than Europe. Modern now became associated more and more with American things speed, movies, and jazz. All three were directly or indirectly manifested in the cafés of the late 1920 s and early $1930 \mathrm{~s}$.

The big new cafés of Ginza transformed the visual images of the modern city in both their interiors and exteriors. From the outside their blazing red and blue neon signs lit up the main street, while inside the sense of brilliance and colour of the neon lights was reinforced by stained glass windows and silvery, light reflective building materials, such as stainless steel, aluminum, glass, mirrors and spotlights. Café Maru and the Ginza Palace led the way in these design innovations which contributed to a sense of modernity associated with bright light and material richness.

With these new cafés the distinction between cafés and bars on the one hand and kissaten (coffeeshops) on the other became clear. Kissaten were places where one went for a meal, not to enjoy alcoholic beverages. Cafés, like bars, offered Western alcoholic drinks, but could provide more food than bars and were usually more Western in their menus, decor and ambience ${ }^{26}$. Jazz music, big band not blues, contributed to the Western ambience and satisfied patrons' desire for a fast «tempo». Not all cafés played music, however.

What came to distinguish the cafés of the late 1920 s and 1930s from both their Japanese predecessors and their ostensible Western models was the changed role of the café waitresses (jokyû). Murobushi Kôshin, a contemporary commentator who extolled the café as the symbol of Japanese modernity, depicted the café waitress as both the flower and spirit of the café. He observed that unlike a European café, a Japanese café did not require music to be a café. One could even imagine a café in Japan without alcohol, he declared, but one could not imagine a café without waitresses ${ }^{2 ?}$. From this it is evident that the café in Japan after the earthquake had become a different place

\footnotetext{
23 Tôkyô Hyakunenshi Henshû linkai (1979, p. 86).

24 Tôkyô Hyakunenshi Henshû linkai $(1979$, p. 271).

25 Seidensticker quoting the novelist Tanizaki Junichirô. Seidensticker (1991, p. 57).

26 Seidensticker (1991, p. 31).

27 Murobushi $(1929$, p. 190).
} 
from its Meiji and even Taishô antecedents. It was no longer a place where Western food and drinks took primary importance. Rather, service, and increasingly erotic service, became its chief attraction. However, while Murobushi acknowledged the sexual attraction of the waitresses, he denied the café's primary function and appeal as a place for arranging sexual assignations. In his view the young generation was interested in «platonic» and «romantic» love, not sex, so it was an atmosphere of love (ren'ai) that brought young people to the cafér.

Other commentators, though not as enamored of the café, also noted that the café provided one of the few places where young men and women could meet and mingle socially. In fact, there was no other place where young women and men could interact as easily, cheaply or directly as in a cafe ${ }^{29}$. Geishas were expensive, too expensive for the young white collar workers or «salarymen » who comprised the majority of café patrons, and too complicated to arrange. One had to go through prescribed procedures at an introductory meeting (machiai) and follow certain etiquette to be entertained by a geisha. «Modern men want a flaming moment of pleasure», noted Murashima Yoriyuki ${ }^{30}$. In this «time of speed» the café enabled men to enjoy an erotic atmosphere openly and easily ${ }^{31}$. Moreover, modern young people wanted romance and an object for their sexual life which the café waitress as a «modern girl» (modan gâru) provided ${ }^{32}$. Again, according to Murashima, it was less carnal desire than a "love feeling" (ren'ai kibun) that drew young men to the cafe ${ }^{33}$. Nevertheless, it was this free mixing of the sexes and the open sexuality of the female employees that challenged established social norms and gender roles.

For women, the café in some views played an important role in their liberation. It offered an opportunity for work to young women without particular education or training as well as opportunities for free love ${ }^{34}$. The 1920 s saw the opening up of new occupations for women, especially middle class women ${ }^{35}$. Besides farming and textile or other factory work, women could engage in work outside the home as typists, nurses, teachers, department store clerks, bus conductors and switchboard operators. Young women from poor rural or urban families, however, did not possess the education or skills for many of these new jobs, nor for the traditional entertainment job of a geisha, and compared to farm or factory work, work in a café was less arduous even though the hours were long. It was also commonly thought that café waitressing paid more money than other jobs, and the celebrity status of some café waitresses attracted even well-known actresses to open cafés in Ginza ${ }^{36}$. According to a 1930 survey, café waitresses pointed to firstly, a good income and secondly, freedom as good aspects of their job ${ }^{37}$.

\footnotetext{
28 Murobushi (1929, pp. 190-191).

29 Matsuzaki $(1986$, p. 82).

30 Murashima (1988, pp. 319-321).

31 Murashima (1988, pp. 319-321).

32 Matsuzaki (1986, p. 80). On the «modern girl» as a transgressive figure, see Silverberg (1991).

33 Murashima (1988, pp. 319-320).

34 Murashima (1988, p. 322; Matsuzaki (1986, p. 83); Murobushi (1929, p. 191).

35 On middle class working women, see Nagy (1991, pp. 199-216); Newell (1997, pp. 17-41).

36 According to a Central Employment Agency survey, «because the money is good" was the second most common reason given for becoming a café waitress. Murashima (1988, p. 323). On actresses opening cafés, see p. 374 .

37 Ôbayashi (1983, p. 85).
} 


\section{THE EROTICIZATION OF THE CAFÉ WAITRESS}

Café waitresses were not employed as prostitutes, and since prostitution remained a legal institution until 1956, despite the efforts of some Christian moral reformers to abolish $\mathrm{it}^{38}$, men could have gone directly to either a licensed or unlicensed prostitute if sex was what they wanted. Moreover, unlike a geisha, a café waitress was not bound like a slave by a contract to the café owner, nor did she have to accept just any patron into a sexual relationship like a licensed prostitute. Nevertheless, several factors worked to push many café waitresses into prostitution after hours, and this became the basis for moral condemnation by a wide variety of social commentators and for the association of cafés with a social climate of «eroguro-nansensu» (erotic-grotesque-nonsense). This widespread moral condemnation of the café waitress's provision of erotic or «ero» service in turn supported police repression and control during the late 1920s and 1930s.

With the rapidly increasing number of cafés in the mid and late 1920s, the demand for waitresses escalated too. People opening new cafés tried to hire waitresses from other cafés rather than advertising for new and inexperienced women, which was one reason for the high turnover rate of café waitresses. Then, when the depression reduced patronage, café owners tried to lure more customers by hiring more waitresses. Large cafés in Tokyo and Osaka had 100 or more waitresses.

However, hiring is not quite the right word, for the café owner did not pay any wages to the waitresses. This is the reason that depression-period café owners could increase the number of waitresses without increasing their expenses. In fact, it was the waitress who had to pay the owner for her meals and the employment of the cooks at the café. She was also responsible for the cost of any drinks, food, matches or other items consumed by her patrons. Until 1929 café owners also collected fines (called kisoku in Osaka and desen in Tokyo) to penalize waitresses for being late for work (between 50 sen and 1 yen) or absent (between 1 and 2 yen, more for a weekend), and in addition charged them for any damages to furnishings caused by patrons ${ }^{39}$.

A waitress's remuneration came from tips, which in 1929 averaged about 2 yen a day in a big city sakariba, but about 50 sen in the outskirts of a city or in a country town. Contrary to popular belief, most waitresses did not earn a lot of money. At the end of the 1920 s only a little over 2 per cent earned more than 100 yen per month. Average incomes ranged between 30 and 50 yen per month, compared to the starting salary of 70-75 yen per month for a male clerk working for the Tokyo Metropolitan Government ${ }^{40}$. The money did not come in evenly over the course of a month, but peaked at the end of the month when salarymen were paid and dwindled with the thickness of their wallets around the middle of the month ${ }^{41}$. Out of this income the waitress also had expenses related to her work - kimonos (a new one each season), cosmetics, hairdresser and laundry costs. A significant proportion of

38 See Garon (1997, ch. 3).

39 Murashima (1988, p. 331).

40 Murashima (1988, p. 327); Tôkyô Hyakunenshi Henshî linkai (1979, p. 262). Ôbayashi's survey found the most common average monthly income to be $30-35$ yen. Only a few waitresses in the big cafés in the central district made 150-200 yen in a month. Ôbayashi (1983, pp. 97-98).

41 Murashima (1988, p. 337). 
waitresses nevertheless saved some money each month, and many gave it to their families. This reflects the fact that the reason most commonly stated for becoming a waitress was financial, in particular to help with the family budget ${ }^{42}$. In a 1930 survey of almost 2000 café waitresses in Osaka, although the largest proportion of waitresses lived with both parents (35.56 per cent), a large number were supporting their divorced or widowed mothers $(17.75 \text { per cent })^{43}$. Another surprisingly large percentage (22.32 per cent) were married ${ }^{44}$.

Both Marxist and non-Marxist social critics as well as government social agency officials blamed the tipping system and café owners' exploitation for the eroticization of café waitresses and the increasing incidence of prostitution after hours. Relying on tips encouraged waitresses to develop their skills at coquetry and seductive manipulation to obtain a larger tip ${ }^{45}$. One government official concluded that poverty was the cause of their resorting to unlicensed prostitution ${ }^{46}$. Café owners also pressured waitresses to offer erotic services. As mentioned earlier, this occurred when the depression stiffened competition for customers, but it was also attributed to an influx of capital from Osaka after the earthquake and with this, the spread of a flashier style of café to Tokyo. Osaka cafés and waitresses were characterized as friendlier than Tokyo café waitresses; they did not put a distance between themselves and the customer. Proprietors had pushed this type of service, for example by having their waitresses stop wearing aprons so that they would be seen more as women rather than as workers and by telling them to chat with patrons and to behave like a friend or girlfriend ${ }^{47}$. Cafés in Dôtonbori, Osaka's main sakariba, were noisier and gaudier than cafés in Ginza. They thrived in the 1920s, challenging the popularity of the traditional theatres in the district with their dazzling lights and jazz music, especially after big cafés emerged in 1927 and 1928 . Their dozens of waitresses, coloured windows, bright coloured lights and gramophone music lured patrons away from the traditional teahouses with geishas.

The Ginza cafés established by Osaka capital included the previously described Ginza Palace. They not only introduced the new ideas about architectural design and decor, but also intensified ero service and devised new kinds of advertising that Tokyo cafés had never thought of before. Placing one waitress per patron, for example, meant that no man would miss out on the seductive experience. In the publicity area, Bijinza Kafê (House of Beauties) created a sensation by flying in 30 waitresses from Osaka by plane, a rarity in 1930, and the Nichirin (The Sun) added to the dazzling glamour of cafés by opening in October with the entire building covered with neon lights ${ }^{48}$.

The women who worked in these big cafés numbered among the few who earned a lot of money from the commodification of their beauty and alluring behaviour, but

42 Murashima (1988, p. 323); Ôbayashi $(1983$, p. 81$)$.

43 Óbayashi (1983, pp. 39-40).

44 Since most café waitresses were in their late teens, it is less surprising that $57.42 \%$ were unmarried. Ôbayashi (1983, p. 64).

45 Murashima (1988, pp. 336-337).

46 This was the main conclusion of a 1930 study of café waitresses and prostitutes conducted by Kusama Yasô, an official with the Social Affairs Bureau of the Tokyo Metropolitan Government. Kusama (1982).

47 Murashima (1983, pp. 171-172)

48 Hatsuda (1993, p. 19). 
Marxist social critics viewed them as well as their poor counterparts in smaller cafés as proletarianized workers merely being used by capitalists. Gonda Yasunosuke regarded café waitresses as «formal» rather than genuine representatives of «modern life», no more than workers in the "modern life industry " ${ }^{49}$. In such views the women had lost, not gained freedom, and the «wretched» salarymen who patronized them did so because they lived in a period of no hope for the future ${ }^{50}$. According to Gonda, «modern life » was a way of living divorced from any productive work or concerns other than consumption and therefore led to the enjoyment of "perverse tastes» in the streets and their extensions, the cafés ${ }^{51}$. Cafés' and café waitresses' association with erotic-grotesque-nonsense was seen as symptomatic of the final stage of capitalism ${ }^{52}$.

\section{POLICE REPRESSION}

Police repression consisting of new restrictive regulations on cafés and arrests of café waitresses and patrons began in the 1920s and continued throughout the 1930s. It shows that government authorities shared with left wing critics as well as Christian reformers the association of cafés and café waitresses with decadence and moral degeneracy. They also shared certain assumptions about women's roles which were revealed in policies adopted toward café waitresses' attempts to form a union. The new restrictive legislation reveals the aspects of the café which authorities regarded as promoting immoral behaviour and more generally exemplifies the prescriptive nature of many pre-1945 Japanese laws. It also highlights the importance placed on the preventive role of the police, the assumed legitimacy of police interference in matters of social life and behaviour, and the expanding nature of that interference during this period of intense social and political turmoil.

Police reports portrayed cafés as harmful to public morals - «cheap and hedonistic». They attributed their appeal to the depressed economic conditions and vaguely referred to «social conditions of the time». They specifically disapproved of waitresses' "coquettish" behaviour, but also blamed café owners for fanning patrons' hedonistic mood by making alterations to structures and equipment. This refers to the changes in architecture and interior decor that took place in the big cafés which prospered in the late 1920s and early 1930s.

Police in Tokyo initially tried to control the perceived harmful effect of these changes in the mushrooming cafés after the earthquake by arresting patrons and waitresses for violations of the «Control Regulations on Machiai Tea Houses, Boat Hotels, Rental Rooms, Restaurants, Eating Houses and Geisha Houses» (Keishichô Order No. 8, April 1895). As noted at the beginning of this essay, the police in Tokyo made 645 arrests for alleged violation of these regulations in 1926 alone. In Osaka restrictions on dancing and dance halls presaged the crackdown on cafés. In 1925 Osaka authorities banned dancing in places serving food and drinks, then in 1927 issued strict regulations on dance halls, such as limits on their hours and a ban on stu-

\footnotetext{
49 Gonda (1929, p. 34).

50 Takada (1983, p. 167).

si Gonda (1929, pp. 33-35).

52 For example, Hori (1983, pp. 184-190).
} 
dents. In 1929, when cafés were still at the peak of their popularity in Osaka, the city government introduced similar restrictions on cafés, and the Tokyo Metropolitan Police Bureau issued a new order stating «Principles for Controlling Cafés and Bars». The new Tokyo order explicitly gave the reason for new administrative actions as proprietors' being «exceedingly harmful to public morals». Both the Osaka and Tokyo city authorities sought to restrict the location of new cafés to nonresidential areas, following the tradition of segregating entertainment districts. They prohibited certain facilities and structures for «easily corrupting» public morals: separate rooms or partitions; a bath for patrons; extremely dark or unusual lighting; a stage. They also set closing time at midnight and prohibited loud music, performances and movies. Here we can see authorities' disapproval of jazz, «modern» stage entertainments and social dancing. They hoped to limit the selling of erotic services by requiring proprietors to check prospective employees' backgrounds and prohibiting waitresses from hailing in customers, acting like geishas, or going out with patrons ${ }^{53}$.

Not satisfied with the effectiveness of these new regulations, the Tokyo Metropolitan Police Bureau issued further regulations for the «Special Restaurant Trade» in 1933. «Special restaurants» were defined as restaurants and eating houses with Western-style facilities where women served at the table. Restrictions on structures and facilities became more precise, for example, allowing only one lounge room per floor, walls or partitions no more than $120 \mathrm{~cm}$ high, and only white lights. Prohibitions on waitresses' wearing «singular clothes» and committing «indecencies» were added, and only one waitress was permitted for each four square metres of lounge space, no doubt a response to proprietors' hiring of more waitresses to attract customers during the depression.

The new regulations gave the police wide discretionary power in approving applications for new special restaurants, relocations, alterations, additions or repairs, for example by allowing disapproval if the application was deemed «inappropriate on the grounds of public peace and morals $»$. In addition, they empowered the chief of a police station (keisatsushochô) to restrict or prohibit « any decoration, facilities, signboards and the like if deemed inappropriate on the grounds of public peace, morals and aesthetic appearances $»^{54}$. He could also order a proprietor to dismiss a waitress if she failed to comply with any of ten prohibitions, including a catch-all that she «must not engage in any other act that may harm public peace and morals $\gg^{55}$. Within the first twelve months under these new regulations, 38 special restaurants had their licenses cancelled, and 375 had their operations suspended ${ }^{56}$.

The following year, police authorities revised the regulations to restrict the patrons of cafés as well as owners and female employees. Adopting the high moral tone of a nursemaid police, Tokyo Metropolitan Police headquarters sent a notice to all district police chiefs with instructions to enforce a ban on students and minors in special restaurants and dance halls. Police authorities were struck by the "alarming" number of students and minors who were frequenting cafés and dance halls, « mixing with the delinquent and forgetting their duty as a student». They condemned students' «self-indulgence and dissolution», and their being «infected by the evil of

53 Keishichôshi Hensan linkai (1962, p. 811).

54 Keishichôshi Hensan Iinkai (1962, pp. 813-814).

55 Keishichôshi Hensan linkai (1962, p. 816).

56 Keishichôshi Hensan linkai (1962, p. 818). 
decadence and corruption ${ }^{57}$. The Police Bureau had consulted with school principals, the Ministry of Education, and the Governor of Tokyo before taking these measures, and its letter seeking their support had also received favourable press coverage. The revised regulations made proprietors responsible for keeping students and minors out - «it is not intended to punish students and minors ».

Nevertheless, during the next several years numerous students as well as waitresses were arrested. One notable crackdown occurred in February 1938 when six police groups descended on sakariba and made more than 2000 arrests on the night of the 15th. Two days later they hit mahjong clubs, cinemas, billiard halls, parks and even department stores, bringing the arrest total to 7373 (7 032 males and 341 females). The stated intention was to offer an opportunity «for warning and introspection for the students, their educators and guardians ${ }^{58}$.

By 1935 more than a dozen prefectures had introduced similar restrictions on cafés and bans on students. Concern about the «morals problem» and proliferation of new restrictions had become so widespread that the Home Ministry decided to issue a national policy to unify regulation of cafés and bars. The new national policy mirrored the Tokyo Metropolitan Police regulations, but also added the intention of limiting the number of waitresses and prohibiting certain makeup and clothing. The ban on students was applied nationwide ${ }^{59}$.

The targeting of students and occurrence of the arrest sweeps in the mid and late 1930s suggest that police and other government officials were becoming more concerned about the café's undermining of traditional social roles and values than its providing a conducive environment for the spread of «dangerous» political ideas. During the 1920 s and early 1930 s café waitresses had formed unions in various cities which were often associated with socialist organizations. One of the earliest organized in Osaka in 1921 began under the influence of labour union activists who gathered in cafés in the western Osaka factory district. This Osaka Café Waitresses League (Ôsaka Jokyû Dômei) raised more than $¥ 1000$ in support of a strike at the Osaka Iron Works when members appeared at a rally in their aprons. When they joined the May Day demonstration of workers in 1922, one waitress was taken to the police station, and when waitresses at the Asahiya café printed international revolutionary songs on napkins and distributed them to patrons, the police ordered the café closed ${ }^{60}$. Similarly, in 1929 when café waitresses planned the organization of another union in response to the Osaka government's proposal for new restrictions on cafés, the police summoned five of the leaders and «gave them a good talking to», according to the Ôsaka Mainichi Shinbun's report ${ }^{61}$. However, although the police no doubt disapproved of the socialist leanings of the leaders, what they argued was that the waitresses should stop being prostitutes rather than organizing a union ${ }^{62}$.

In fact, police officials expressed a paternalistic concern for the health and welfare of café waitresses as well as prostitutes and other women in the «entertainment» industry. In speeches to geishas and licensed prostitutes they warned the

\footnotetext{
57 Keishichôshi Hensan linkai (1962, p. 825).

s8 Keishichôshi Hensan linkai (1962, pp. 825-830).

59 Kafê taisaku (1935, p. 38).

60 Murashima (1983, pp. 174-175).

61 Ôsaka Mainichi Shinbun (1995, p. 170).

62 Murashima (1983, p. 181).
} 
women to protect themselves against venereal diseases. Police officials also recognized that most of these women resorted to prostitution due to poverty. They tried to some extent to limit brothel or café owners' exploitation, in the latter's case by introducing bans on penalty fines for waitresses in the new restrictions on cafés. At the same time their admonitions reveal their assumption that all women were destined to marry and have a family - « to be prepared for the day you marry, make sure you learn women's skills such as sewing, cooking and home management $\gg^{63}$.

Geishas and licensed prostitutes represented women in the traditional entertainment industry, but café waitresses represented the «modern girl» whose ideas of «love » and «companionate marriage» challenged the patriarchal family system which formed the base for the Japanese family-state. Police officials in addition viewed waitresses' engagement in unlicensed prostitution with disapproval because it escaped their supervision and control, just as students' patronizing of cafés created «not only a grave concern for the future of youth and students, but also... police control of morals ${ }^{64}$.

In the early and mid 1930s when the nation faced an international crisis, these challenges to social roles and to police authority assumed greater importance, especially since radical socialism and communism had been destroyed by the time the large-scale arrests of students and waitresses took place in the mid and late $1930 \mathrm{~s}^{65}$. Elimination of any objective threat from the left did not end the police's fear of its resurgence, but now the police gave more attention to preventing and halting a deterioration of public morals which would weaken the national body. This coincided with the government campaign to boost «spiritual mobilization» launched in 1937. The concern to prevent students and other youth from being «infected» by «decadence and corruption» suggests that the cafe's threat was by the 1930 s more social than political. Tosaka Jun's view that public morals symbolized thought and that interference with public morals was intended as thought control is accurate, but «thought» was a modernity symbolized by the café rather than socialism.

Japanese imperialism of the 1930s and 1940s is often regarded as Japan's rejection of Western dominance of international affairs. Similarly, as police repression of cafés reveals, the domestic repression of the same period was not only a product of wartime requirements for national political unity, but also an attempt to counter changes in social values and behaviour associated with Westernization. The war represented a fight against modern, Western individualism, materialism and sexuality as well as Western imperialist hegemony. The state's efforts to unify and mobilize the nation's spiritual resources for war consequently enhanced the role played by the police in moral guidance and daily social life in addition to elevating its status as defender of the nation against dangerous political thought.

\section{Elise K. TIPTON University of Sydney School of Asian Studies Sydney NSW 2006 \\ Australia \\ elise.tipton@asia.usyd.edu.au}

63 From a speech to a gathering of licensed prostitutes. Jônan (1926, p. 164).

64 Keishichôshi Hensan Iinkai (1962, p. 825).

65 The arrest of Central Committee members of the Japan Communist Party in October 1932 marked the end of an organized Communist movement until the end of the Second World War. 


\section{REFERENCES}

Dôke, S., Baishunfu ronkô [A study of prostitutes] (originally 1928), in Minami, H. (Ed.), Kindai shomin seikatsushi, vol. 10, Tokyo, San'ichi Shobô, 1988.

Fosdick, R., European Police Systems, New York, The Century Co., 1916.

Garon, S., Molding Japanese Minds, Princeton, Princeton University Press, 1997.

Gonda, Y., Modan seikatsu to hentai shikôsei [Modern life and perverse tastes], Kaizô, June $1929,11,6$, p. 34.

Hatsuda, T., Kafê to kissaten [Cafés and coffee shops], INAX Album 18, Tokyo, INAX Shuppan, 1993.

Hori, M., Gendai jokyûron [A discussion of modern café waitresses] (originally 1931), in Minami, H. (Ed.), Gendai no esupuri, 1983, 188, pp. 184-190.

Hunt, A., Governing Morals: A Social History of Moral Regulation, Cambridge, Cambridge University Press, 1999.

Jônan, I. (Ed.), Keisatsu kôen kunjishû [A collection of police speeches], Tokyo, Shôkadô, 1926.

Kafê taisaku [Countermeasures against cafés], Kakusei, March 1935, 25, 3, p. 38.

Kamiyanagi, N., Keisatsu seishin ni kansuru jakkan no kôsatsu [Some comments related to police spirit], Keisatsu Kyôkai zasshi, Jan. 1925, 293, pp. 18-19.

Keishichôshi Hensan linkai (Ed.), Keishichôshi, Meiji hen [A history of the Tokyo Metropolitan Police Bureau, Meiji volume], Tokyo, Keishichôshi Hensan Iinkai, 1959.

Keishichôshi Hensan Iinkai (Ed.), Keishichô shi, Shôwa zenpen [The history of the Tokyo Metropolitan Police Bureau, Early Shôwa volume], Tokyo, Keishichôshi Hensan Iinkai, 1962.

Kuroda, S., Nihon keisatsu shi no kenkyû [A study of the history of the Japanese police], Tokyo, Reibunsha, 1963.

Kusama, Y., Jokyû to baishôfu [Café waitresses and prostitutes], in the series Kindai fujin mondai meichô senshû zoku hen, vol. 9, Tokyo, Nihon Tosho Sentâ, 1982.

Matsuzaki T., Ginza, Tokyo, Shinsensha, 1986.

Murashima, Y., Kanraku no ôkyû - kafê [Palace of pleasures - the café] (originally 1929), in Minami, H. (Ed.), Kindai shomin seikatsushi, vol. 10, Tokyo, San'ichi Shobô, 1988, pp. 318-379.

Murashima, Y., Ôsaka kafe dan'atsushi [A history of the repression of Osaka cafés] (originally 1929), in Minami, H. (Ed.), Gendai no esupuri, 1983, 188, pp. 170-183.

Murobushi, K. (or T.), Kafe shakaigaku [A sociological study of the café], Chûô kôron, Sept. 1929, pp. 188-191.

Nagy, M., Middle-class working women during the interwar years, in Bernstein, G. (Ed.), Recreating Japanese Women, 1600-1945, Berkeley and Los Angeles, University of California Press, 1991, p.199-216.

Newell, S., Women primary school teachers and the state in interwar Japan, in Tipton, E.K. (Ed.), Society and the State in Interwar Japan, London, Routledge, 1997, pp. 17-41.

Ôbayashi, M., Jokyâ seikatsu no shin kenkyû [A new study of the lives of café waitresses], in the series Kindai fujin mondai meichô senshû, Shakai mondai hen, vol. 3, Tokyo, Nihon Tosho Sentâ, 1983.

Ôsaka Mainichi Shinbun [Osaka Daily Newspaper], 18 August 1929, reprinted in Suzuki, Y. (Ed.), Nihon josei undô shiryô shûsei, vol. 7, Seikatsu/rôdô IV, Tokyo, Fuji Shuppan, 1995, p. 170.

Seidensticker, E., Tokyo Rising, Cambridge, Ma., Harvard University Press, 1991. 
Silverberg, M., The modern girl as militant, in Bernstein, G. (Ed.), Recreating Japanese Women, 1600-1945, Berkeley and Los Angeles, University of California Press, 1991, pp. 239-266.

Takada, T., Kafe, chian Nihon [Café, public peace Japan] (originally 1929), in Minami, H. (Ed.), Gendai no esupuri, 1983, 188, pp. 167-169.

Teruoka, Y., The pleasure quarters and Tokugawa culture, in Gerstle, C.A. (Ed.), Eighteenth Century Japan: Culture and Society, Sydney, Allen and Unwin, 1989, pp. 3-32.

Tipton, E.K., The Japanese Police State: The Tokkô in Interwar Japan, Sydney and Honolulu, Allen and Unwin and University of Hawaii Press, 1991.

Tôkyô Hyakunenshi Henshû Iinkai (Ed.), Tôkyô hyakunenshi [A hundred year history of Tokyo], vol. 5, Tokyo, Tôkyô Hyakunenshi Henshû linkai, 1979.

Tosaka, J., Ken'etsu shita no shisô to fûzoku [Thought and public morals under censorship], in Minami, H. (Ed.), Gendai no esupuri, 1983, 188, pp. 44-49.

Westney, D.E., Imitation and Innovation, Cambridge, Ma., Harvard University Press, 1987. 